\title{
Electrolytic Removal of Metals Using a Flow-Through Cell with a Reticulated Vitreous Carbon Cathode
}

\author{
Rodnei Bertazzoli*, Rosivânia C. Widner, Marcos R.V. Lanza, \\ Rosana A. Di Iglia, and Maria F.B. Sousa \\ Universidade Estadual de Campinas, Departamento de Engenharia de Materiais - \\ FEM, C.P. 6122, 13083-970 Campinas - SP, Brazil; e-mail: bertaz@fem.unicamp.br
}

Received: July 23, 1996; May 8, 1997

\begin{abstract}
O objetivo do presente trabalho foi estabelecer um processo eletrolítico para remover metais de efluentes aquosos usando um catodo tridimensional de carbono vítreo reticulado. Durante o desenvolvimento do trabalho foi estudado a influência do fluxo do eletrólito e da porosidade do eletrodo. A célula eletrolítica utilizou potenciais tais que a reação de redução ocorreu sob controle de transporte de massa. A célula demonstrou eficiência na remoção de chumbo, zinco e cobre, reduzindo a concentração desses metais de $50 \mathrm{mg} \cdot \mathrm{L}^{-1}$ a $0,1 \mathrm{mg} \cdot \mathrm{L}^{-1}$ em 20 min de recirculação da solução.

The aim of the present study was to establish an electrolytic method for the removal of metals from wastewater using a three dimensional, reticulated vitreous carbon cathode. During the development of the experimental set up, particular attention was paid to the electrolyte flow rate and to the cathode porosity. The electrolytic cell employed potential values in such a way that the metals reduction reaction occurred under mass transport control. These potentials were determined by hydrodynamic voltammetry on a vitreous carbon rotating disc electrode. The cell proved to be efficient in removing copper, zinc and lead and it was able to reduce the levels of these metals from $50 \mathrm{mg} / \mathrm{L}$ to $0.1 \mathrm{mg} / \mathrm{L}$.
\end{abstract}

Keywords: : electrolytic removal of metals, three dimensional electrodes, electrochemical reactors

\section{Introduction}

The quality of water resources and of the environment in general is a permanent concern and has resulted in new solutions for old problems in the field of wastewater treatments. In particular, new efforts have been made at reducing the sources of pollutants and at improving the efficiency of waste treatments.

The toxicity of heavy metals has been known for many years, and the clinical symptoms of prolonged exposure to a heavy metal-contaminated environment are well defined $^{1,2}$. Heavy metals enter waterways via effluent discharges from electroplating, metal finishing, explosive, pigments and paint producing, and metal/mechanics manufacturing industries in general. As a result of their high toxicity, the concentration of highly toxic metallic ions in drinking water is restricted to few $\mathrm{ppb}^{3}$.
The increase in legal pressures and restrictions are forcing industries to accept responsibility for the treatment or storage of waste in an attempt to minimize pollution. The permanent responsibility to care for waste materials "from cradle-to-grave" is encouraging a move towards zero-effluent discharge and the adoption of solutions for the source of effluents rather than treating the waste at the end of the industrial process.

Electrochemical technology offers an efficient means of controlling pollution as it provides removing of heavy metals via redox reactions. The literature on metal ion removal from aqueous electrolytes using three dimensional electrode cells is extensive ${ }^{4-16}$.

In this paper we present an electrolytic cell with a porous cathode of reticulated vitreous carbon (RVC) designed to remove metals from aqueous streams. The equip- 
ment has been tested in copper, lead and zinc removal. By flowing simulated effluents metal ion containing through porous cathodes, it is possible to achieve both high mass transfer rates and large surface areas for the electrochemical reaction. Metals ions in such solutions are reduced at the inner surface of the porous electrodes as the electrolyte is percolated through the cell.

The choice of RVC for the porous cathode is based on the observations ${ }^{17}$ that this material a) is chemically and electrochemically inert over a wide range of potentials and on a wide variety of chemicals, b) has a high specific surface area within the porous structure that is accessible to electrochemically active species, c) has a high fluid permeability, d) is easily shaped as required by cell design considerations and has good mechanical resistance.

\section{Experimental}

The development of the electrolytic cell for metals removal was carried out in two stages. Initially, a voltammetric study of the $\mathrm{Cu}(\mathrm{II}), \mathrm{Pb}$ (II) and $\mathrm{Zn}$ (II) reduction reaction on a glassy carbon rotating disc electrode was performed in order to determine the range of potentials over which this reaction is controlled by mass-transfer. Subsequently, a potential value within this interval was selected and applied to a flow-through electrolytic cell containing a reticulated vitreous carbon cathode. The electrolyte flow rate and the cathode porosity were varied in order to establish the best conditions for metal removal.

\section{Apparatus}

All electrochemical experiments were performed using a Model 273 A potentiostat/galvanostat system controlled by the software Model 270/250 (both from EG\&G Princeton Applied Research Corporation). In both stages, a threeelectrode cell was used, as described below. A Model AA 12/1475 Varian spectrometer was employed to determine the $\mathrm{Cu}(\mathrm{II}), \mathrm{Pb}(\mathrm{II})$ and $\mathrm{Zn}(\mathrm{II})$ concentration, using an air/acetylene flame.

\section{Chemicals and materials}

All reagents were of analytical grade and did not undergo further purification. Distilled and deionized water was used to prepare all solutions. The testing containing metallic ions solutions were prepared in such away that the metallic concentration was around $50 \mathrm{mg} / \mathrm{L}$. Copper solution was prepared from $\mathrm{CuSO}_{4}$ plus $\mathrm{Na}_{2} \mathrm{SO}_{4}(0.1 \mathrm{~mol} / \mathrm{L})$ and boric acid $(0.5 \mathrm{~mol} / \mathrm{L})$, with a final $\mathrm{pH}$ of 4 . The 50 $\mathrm{mg} / \mathrm{L} \mathrm{Pb}(\mathrm{II})$ solution was prepared from $\mathrm{Pb}\left(\mathrm{NO}_{3}\right)_{2}$ using boric acid $(0.5 \mathrm{~mol} / \mathrm{L})$ plus sodium nitrate $(0.05 \mathrm{~mol} / \mathrm{L})$, $\mathrm{pH} 4$. Zinc solution was prepared from $50 \mathrm{mg} / \mathrm{L}$ of $\mathrm{Zn}(\mathrm{II})$ as $\mathrm{ZnCl}_{2}, 0.1 \mathrm{~mol} / \mathrm{L}$ of $\mathrm{KCl}$ and $0.1 \mathrm{~mol} / \mathrm{L}$ of boric acid, at $\mathrm{pH}$ 5.5. The atomic absorption standards were prepared from Titrisol standard solutions (Merck).

\section{Hydrodynamic voltammetry}

The hydrodynamic voltammetric experiments were carried out in a conventional three-electrode cell with separated compartments for each electrode. A glassy carbon rotating disc electrode (GCRDE) Model 616 (PARC) as a working electrode, a large-surface platinum counter-electrode, and a saturated calomel reference electrode (SCE) within a Luggin capillary, were used. The glassy carbon electrode was polished to a mirror-like surface, using $1.0 \mu \mathrm{m}, 0.3 \mu \mathrm{m}$ and $0.04 \mu \mathrm{m}$ alumina slurries, consecutively, on polishing clothes. The current-voltage curves were obtained for several rotations $(400,900,1,600,2,500$ and 3,500 rpm) by cycling the working electrode potential (one cycle). All experiments were carried out at room temperature (around $298 \mathrm{~K}$ ).

\section{Flow-through cell configuration}

The dual continuous-flow cell design is shown schematically in Fig. 1a. The system consisted of an electrochemical cell, of two 4.0 L PVC reservoirs for catholyte and anolyte, of two recirculation pumps, and of two sets of flowmeters, with a flow range from 60 to $600 \mathrm{~L} / \mathrm{h}$, for controlling the catholyte and anolyte flow rates. These components were connected together by polyvinylchloride and polyethylene tubes.

The electrochemical cell shown in Fig. 1b was made from five Nylon plates $(13 \times 30 \times 1.25 \mathrm{~cm})$ assembled in a "sandwich" formation. The cell was divided into a cathodic compartment and two interlinked anodic compartments, separated by a Nafion 417 membrane. The cathodic chamber was fixed between two flow spreading meshes in order to make the distribution profile uniform. To prevent electrolyte leakage, rubber joints were placed between each of the cell components. The cathodic compartment consisted of a rectangular Nylon frame in which a block of reticulated vitreous carbon $(5.0 \times 15.0 \times 1.25 \mathrm{~cm})$ was fixed. The electrical contact was made of a stainless steel plate which was located on one of the inner sides of the frame and welded to a copper wire ( $4 \mathrm{~mm}$ in diameter). The electrical contact was cemented to the RVC with a conducting silver cement. Two lead sheets $(5.0 \times 15.0 \times 0.05 \mathrm{~cm})$, each located in a $1.0 \mathrm{~cm}$ deep cavity within the end plates (Fig. 1b), comprised the anodes for the removal of copper. Stainless steel was used for lead removal, and zinc electrolyte demanded platinum anodes due to the presence of chloride. Copper wires were soldered to the two anode plates in order to provide the electrical contact. A saturated calomel reference electrode within a Teflon Luggin capillary entered the catholyte compartment through a hole drilled in the upper side of the RVC cathode-containing frame. The cell had two electrolytes entrances and two electrolyte exits. In this system, the electrolytes flow separately and simultaneously 
in a closed circuit through the catholyte and anolyte compartments.

\section{Procedure}

After assembling the electrochemical cell, the flow system was loaded with $3.5 \mathrm{~L}$ of catholyte and anolyte, each in a separate reservoir. The catholyte consisted of the solutions described above. The anolyte composition was the same as the catholyte, with the exception of the metal ions, and the flow rates of both electrolytes were adjusted to the same value. Then, a constant potential of $-0.3 \mathrm{~V}$ for copper, $-0.8 \mathrm{~V}$ for lead and $-1.35 \mathrm{~V} v s$. SCE for zinc was applied to the cell from a potentiostatic power supply, in
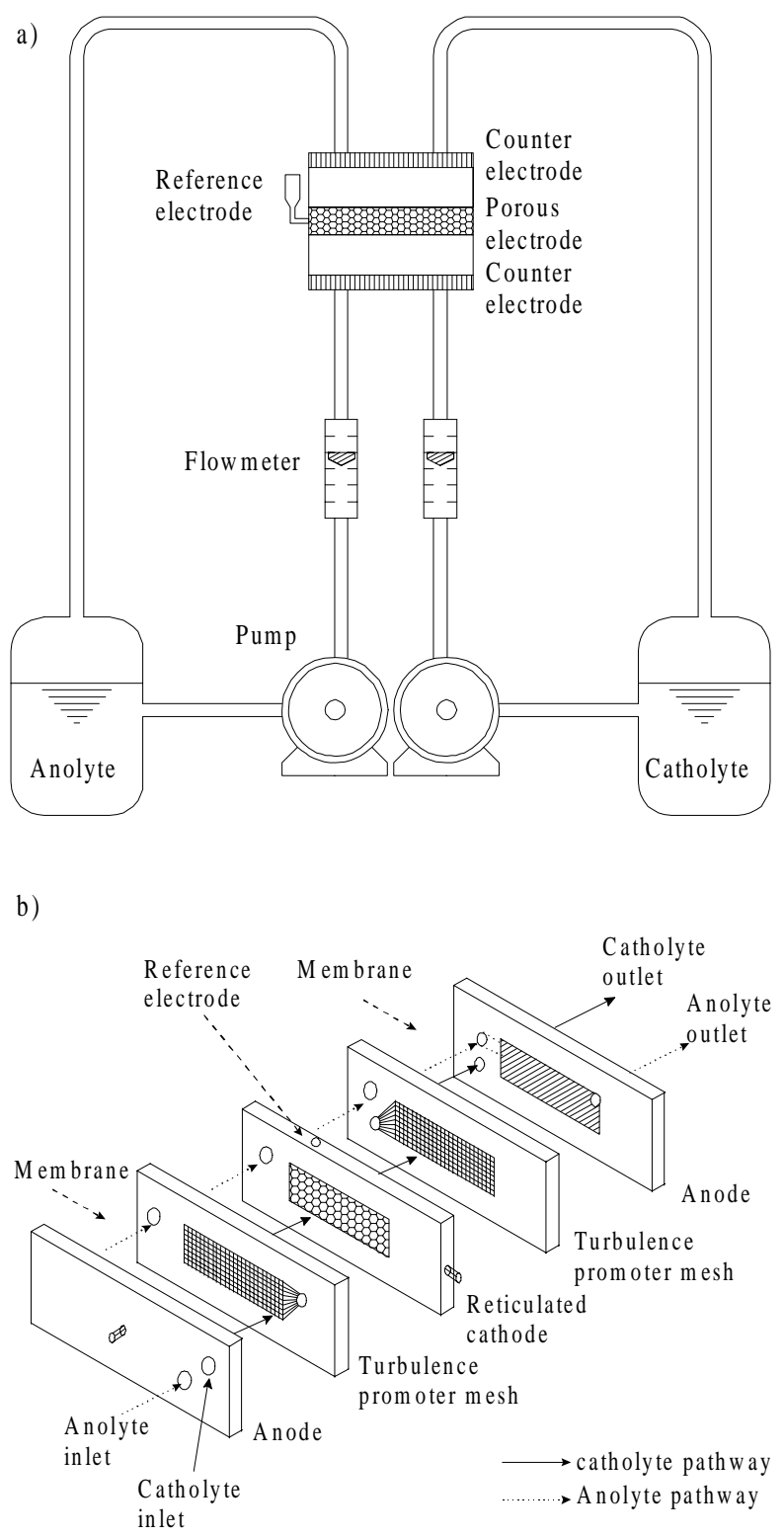

Figure 1. (a) Dual continuous-flow cell design. (b) Electrolytic cell used for metal removal. the controlled-potential mode, for two hours. As observed in the preliminary hydrodynamic voltammetric study, the reduction of those metals at these potentials is mass transport-controlled. At predetermined intervals, the solution leaving the cathodic compartment was sampled, and the remaining metal concentration was quantified by atomic absorption spectrometry, in order to monitor the effectiveness of electrolysis.

\section{Results and Discussion}

As stated earlier, the development of the electrolytic cell for the removal of metals was accomplished in two phases. In order to determine the appropriate reduction potential for the removal of $\mathrm{Cu}$ (II), $\mathrm{Pb}$ (II) and $\mathrm{Zn}$ (II) ions from the chosen medium under conditions of turbulence, a preliminary hydrodynamic voltammetric study was carried out. Subsequently, this potential was applied to the electrolytic cell under several combinations of electrolyte flow rate and RVC cathode porosity.

\section{Preliminary hydrodynamic voltammetric experiments}

Figures 2, 3 and 4 show a series of voltammograms obtained in the hydrodynamic mode for solutions containing $50 \mathrm{mg} / \mathrm{L}$ of each metal in the supporting electrolyte as described in the experimental section. The potential was scanned on a glassy carbon rotating disc electrode (area = $\left.0.12 \mathrm{~cm}^{2}\right)$ using five different rotation rates $(400,900$, $1,600,2,500$ and 3,600 rpm). It should be noted that, in the cathodic scan, all the curves in the three figures show waves for the reduction of $\mathrm{M}(\mathrm{II})$ to $\mathrm{M}$, with a well-defined limiting current plateau extending over a large potential range. The value of the limiting current was dependent on the GCRDE rotation rate. This behavior is characteristic of a mass-transfer controlled process. According to the literature, the application of the Levich equation is an appropriate test to verify whether an electrode process is conducted under a

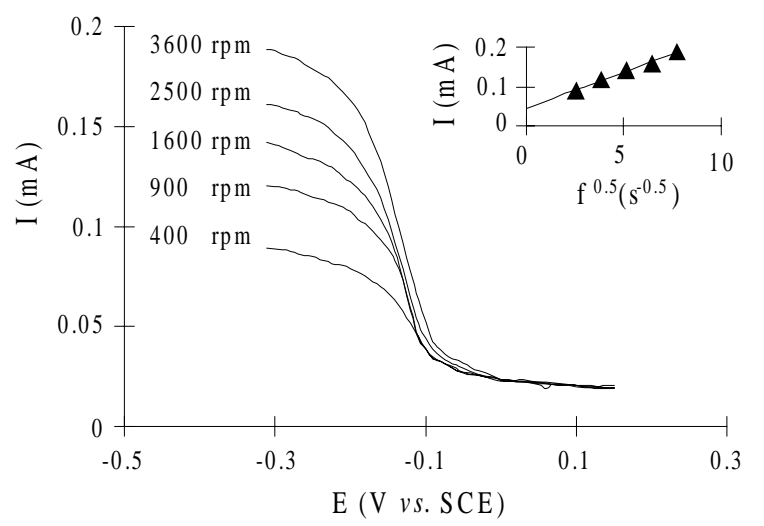

Figure 2. Voltammograms obtained on a glassy carbon rotating disc electrode. Solution of $50 \mathrm{mg} / \mathrm{L}$ of $\mathrm{Cu}(\mathrm{II})$. Scan rate $20 \mathrm{mV} / \mathrm{s}$. Rotation rates as indicated in the graph. Inset: Levich plot using the limiting current values taken at the mid point of the plateaus. 


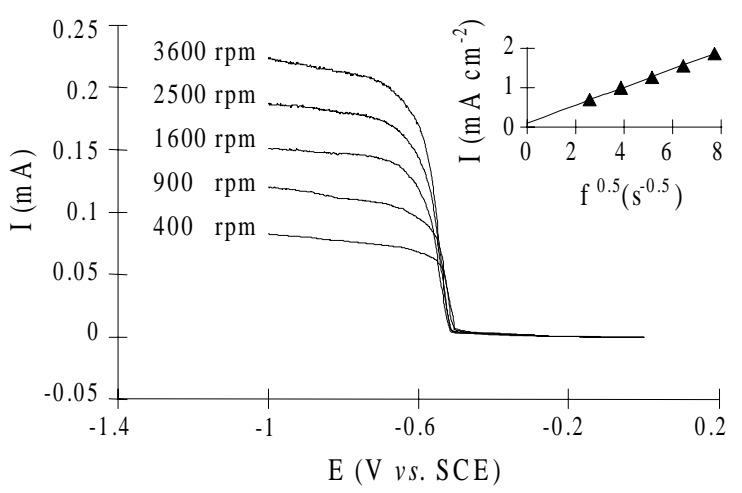

Figure 3. Voltammograms obtained on a glassy carbon rotating disc electrode. Solution of $50 \mathrm{mg} / \mathrm{L}$ of $\mathrm{Pb}(\mathrm{II})$. Scan rate $10 \mathrm{mV} / \mathrm{s}$. Rotation rates as indicated on the graph. Inset: Levich plot using the limiting current values taken at the mid point of the plateaus.

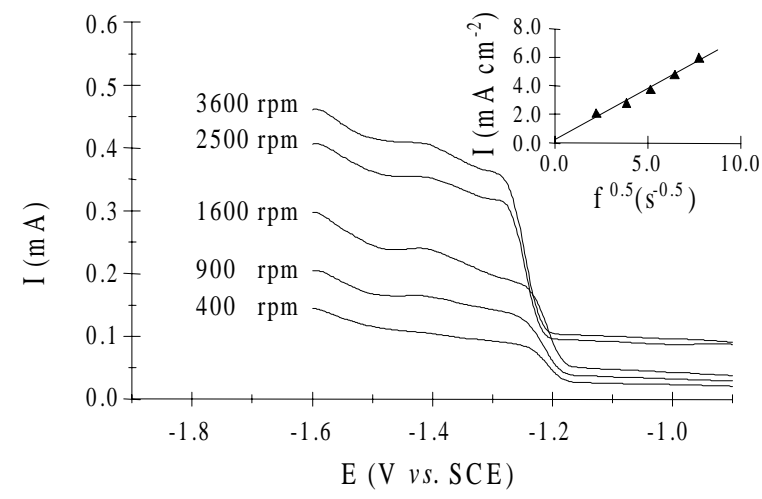

Figure 4. Voltammograms obtained on a glassy carbon rotating disc electrode. Solution of $50 \mathrm{mg} / \mathrm{L}$ of $\mathrm{Zn}(\mathrm{II})$. Scan rate $2 \mathrm{mV} / \mathrm{s}$. Rotation rates as indicated on the graph. Inset: Levich plot using the limiting current values taken at the mid point of the plateaus.

mass-transfer controlled condition ${ }^{18}$. The limiting currents measured at the mid point of the plateaus were plotted as a function of the square roots of the rotation rates (I vs. $\omega^{1 / 2}$ ) as shown in the insets of Figs. 2, 3 and 4. As predicted by the Levich equation, the plots were linear, confirming the fact that under the conditions of this study, copper, lead and zinc deposition became mass-transport controlled at potentials more negative than $-0.2,-0.6$ and $-1.2 \mathrm{~V} v s$. SCE, respectively.
Efficiency of metal removal by the recirculating flowthrough cell

In flow-through cell performance studies, the removal of $\mathrm{Cu}(\mathrm{II}), \mathrm{Pb}$ (II) and $\mathrm{Zn}$ (II) was conducted in the recirculation mode. The depletion of the metals concentration by potentiostatic electrolysis at the reticulated carbon cathodes was evaluated by measuring the remaining metallic concentration in the catholyte compartment solution as a function of the electrolysis time. The levels of metals were quantified by atomic absorption spectrometry. Each experiment was carried out using $3.5 \mathrm{~L}$ of a solution with the same composition as that used in the preliminary experiments; the anolyte contained only a supporting electrolyte with no metallic ions. A potential of $-0.3 \mathrm{~V}$ for copper, -0.8 $\mathrm{V}$ for lead and $-1.35 \mathrm{~V} v$ s. SCE for zinc was applied at the RVC cathode for the electrodeposition of the metals. These potential values were the mid point of the limiting current plateaus obtained in the experiments with the GCRDE.

As a preliminary test of the cell performance removal of copper from sulphate media was chosen due to its well known behavior under bulk electrolysis conditions that is widely found in the literature ${ }^{4-6,9,10}$. Figure 5 shows the decay of copper concentration during the time of electrolysis. A 60 ppi RVC cathode was used under a flow rate of $120 \mathrm{~L} / \mathrm{h}$. After $15 \mathrm{~min}$. of recirculation in open circuit, 48 $\mathrm{mg} / \mathrm{L}$ of copper were found in solution using AAS analysis. After the cathode polarization at $-0.3 \mathrm{~V} v s$. SCE the amount of copper remaining in solution decreased exponentially with the time. After $30 \mathrm{~min}$. of polarization the concentration was $0.1 \mathrm{mg} / \mathrm{L}$. Literature reports ${ }^{10}$ removal rates of $2.1 \mathrm{mg} . \mathrm{L}^{-1} \mathrm{~min}^{-1}$ considering the time taken for $90 \%$ of removal from the initial value $\left(\mathrm{t}_{90 \%}\right)$. In our case the cell shown $6.6 \mathrm{mg} . \mathrm{L}^{-1} \mathrm{~min}^{-1}$ of removal rate. Table 1 shows the comparison between the results from the literature with data taken from Fig. 5. The better performance of the cell designed for this work is evident. Using a lower porosity $\mathrm{RVC}$ cathode, lower potential for $\mathrm{Cu}$ (II) reduction, which means saving of energy, and lower flow rate, that makes the details of construction simpler, our cell presented a greater removal rate than the design used in Ref. 10.

In a new series of experiments using lead containing electrolyte the role of the flow rate on the cell performance was investigated. Electrolysis was carried out using potential of $-0.8 \mathrm{~V} v s$. SCE. Figure 6 illustrates the decreasing in normalized $\mathrm{Pb}(\mathrm{II})$ concentration, $[\mathrm{C}(\mathrm{t}) / \mathrm{C}(0)]$, plotted against the length of time of electrolysis, using different

Table 1. Removal of copper ion from sulphate medium. Comparison between cell performances.

\begin{tabular}{lcccccc}
\hline & $\begin{array}{c}\text { RVC grade } \\
(\mathrm{ppi})\end{array}$ & $\begin{array}{c}\text { Flow rate } \\
\left(\mathrm{m} \mathrm{s}^{-1}\right)\end{array}$ & $\begin{array}{c}\text { Initial }[\mathrm{Cu}(\mathrm{II})] \\
(\mathrm{mg} / \mathrm{L})\end{array}$ & $\begin{array}{c}\text { t90\% } \\
(\mathrm{min})\end{array}$ & $\begin{array}{c}\text { Removal rate } \\
(\mathrm{mg} / \mathrm{L} \mathrm{min})\end{array}$ & $\begin{array}{c}\text { Final }[\mathrm{Cu}(\mathrm{II})] \\
(\mathrm{mg} / \mathrm{L})\end{array}$ \\
\hline Ref. 10 & 100 & 0.04 & 52 & 22.5 & 2.1 & 0.4 \\
This work & 60 & 0.004 & 48 & 6.5 & 6.6 & 0.1 \\
\hline
\end{tabular}




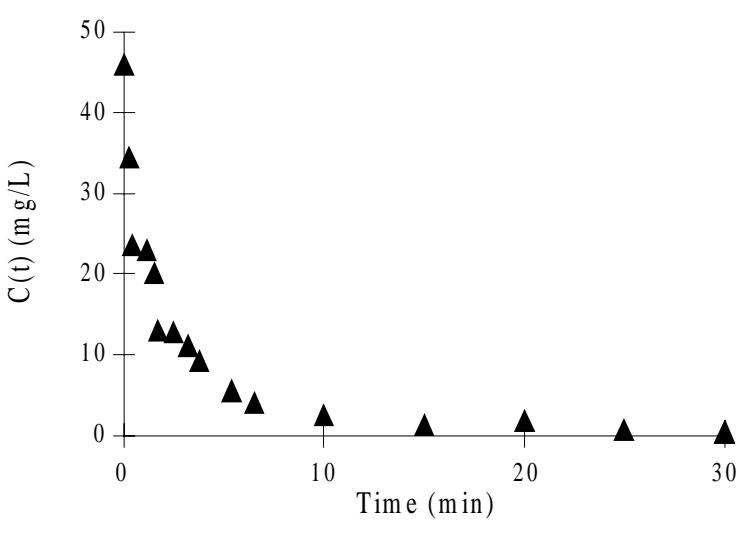

Figure 5. Concentration $v s$. time curves for copper removal experiment obtained for a $120 \mathrm{~L} / \mathrm{h}$ flow rate and cathode porosity of $60 \mathrm{ppi}$. Initial concentration was $48 \mathrm{mg} / \mathrm{L}$ of $\mathrm{Cu}(\mathrm{II})$. Potential of $-0,3 \mathrm{~V}$ vs. SCE.

flow rates $(60,120$ and $240 \mathrm{~L} / \mathrm{h})$ for a $60 \mathrm{ppi}$ cathode. All the curves had the same profile in which the lead ion concentration dropped nearly exponentially with the time. Figure 6 also shows that the $\mathrm{Pb}$ (II) concentration decreased from the initial values to less than $0.1 \mathrm{mg} / \mathrm{L}$ after an electrolysis time of 20 to $30 \mathrm{~min}$, depending on the flow rate. The data show that the reduction of lead into the RVC cathode is sensitive to the flow rate. Removal rate increases with the flow rate used for the cell operation. Table 2, that shows the effect of the flow rate on the removal rate, also includes data for a 80 ppi esponje.

Figure 6 also shows in the inset that plot of $\ln [\mathrm{C}(\mathrm{t}) / \mathrm{C}(0)]$ vs. time of recirculation during cathodic polarization is linear. Controlled potential electrolysis at a reticulated carbon cathode in a similar recycle-mode was also investigated by Pletcher et al. ${ }^{9}$ According to these authors, batchrecycle systems similar to that employed in the present work may be modeled very satisfactorily as a simple batch reactor, with no significant need to use a batch-recycle model. For a batch system:

$$
\ln \left[\frac{\mathrm{C}_{(\mathrm{t})}}{\mathrm{C}_{(0)}}\right]=\frac{-\mathrm{V}_{\mathrm{e}} \mathrm{k}_{\mathrm{m}} \mathrm{A}_{\mathrm{e}}}{\mathrm{V}_{\mathrm{r}}} \mathrm{t}
$$

where $\mathrm{Ve}$ is the cathode volume, $\mathrm{A}_{\mathrm{e}}$ is the specific surface area (i.e., the active area/unit volume of the cathode), $\mathrm{Vr}$ is the total volume of catholyte in the cell, $\mathrm{k}_{\mathrm{m}}$ is the mass transfer coefficient and $\mathrm{C}(\mathrm{t})$ is the concentration of the metallic ion as a function of electrolysis time.

Since $\mathrm{Ve} / \mathrm{Vr}$ is a constant, the values of $\mathrm{k}_{\mathrm{m}} . \mathrm{A}_{\mathrm{e}}$, taken from the slopes of $\ln C(t) / C(0)$ vs. time plots give an indication of cell efficiency for each operating condition. If we take into account that $\mathrm{V}_{\mathrm{e}} / \mathrm{V}_{\mathrm{r}}$ is 0.027 for the cell configuration used in this study and the approximate electrode areas taken from the RVC manufacturer's literature, it is possible to calculate the mass transport coefficient, $\mathrm{k}_{\mathrm{m}}$, also presented in Table 2. It is possible to note that the mass transport coefficient increases with the flow rate. For higher flow rates, hydrodynamic condition improves the mass transfer within the porous cathode probably reducing the diffusion layer thickness. Results depicted in Table 2 also indicates that the cathode porosity can be used for optimizing the cell performance for the removing of metals.

In order to investigate how does the cathode porosity modify the efficiency of the cell a new set of experiments were carried out using a zinc containing electrolyte which composition was described in the experimental section. The influence of the cathode porosity on the effectiveness of electrolysis is depicted in Fig. 7 which shows the experiments of zinc removal using potential of $-1.35 \mathrm{~V} v s$. SCE. Different RVC porosities (45, 60, 80 and 100 ppi) were

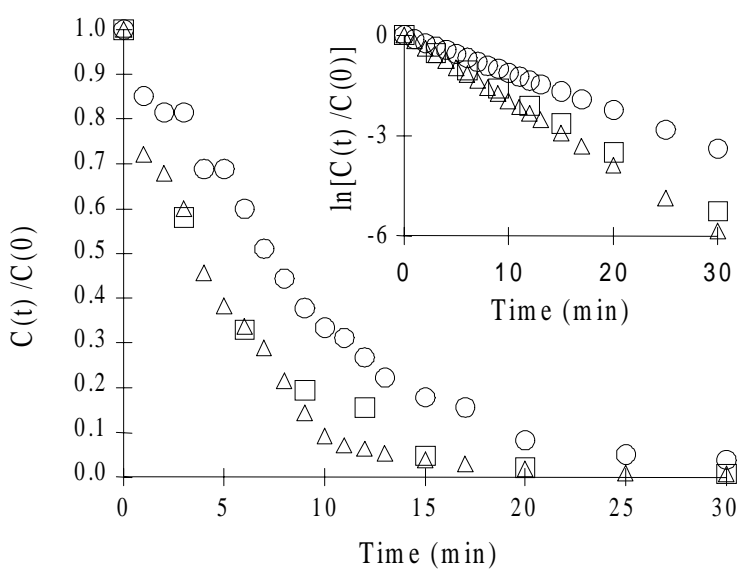

Figure 6. Normalized concentration $[\mathrm{C}(\mathrm{t}) / \mathrm{C}(0)] v s$. time for lead removal experiment obtained for a 60 ppi cathode, using flow rates of (o) $60,(\bullet)$ 120 and $(\Delta) 240 \mathrm{~L} / \mathrm{h}$. Initial $\mathrm{Pb}(\mathrm{II})$ concentration as shown in Table 2. Potential of $-0.8 \mathrm{~V} v s$. SCE. Inset: Plot of $\ln [\mathrm{C}(\mathrm{t}) / \mathrm{C}(0)] v s$. time for the data shown.

Table 2. Effect of the flow rate on the removal rate and on the mass transport coefficient for two different RVC esponjes.

\begin{tabular}{lccccccccc}
\hline & \multicolumn{3}{c}{$60 \mathrm{~L} / \mathrm{h}$} & & & $120 \mathrm{~L} / \mathrm{h}$ & & \multicolumn{2}{c}{$240 \mathrm{~L} / \mathrm{h}$} \\
\cline { 2 - 10 } RVC (ppi) & $\begin{array}{c}\mathrm{C}(0) \\
(\mathrm{mg} / \mathrm{L})\end{array}$ & $\begin{array}{c}\mathrm{t} 90 \% \\
(\mathrm{~min})\end{array}$ & $\mathrm{k}_{\mathrm{m}}{ }^{*}$ & $\begin{array}{c}\mathrm{C}(0) \\
(\mathrm{mg} / \mathrm{L})\end{array}$ & $\begin{array}{c}\mathrm{t} 90 \% \\
(\mathrm{~min})\end{array}$ & $\mathrm{k}_{\mathrm{m}}{ }^{*}$ & $\begin{array}{c}\mathrm{C}(0) \\
(\mathrm{mg} / \mathrm{L})\end{array}$ & $\begin{array}{c}\mathrm{t}_{90 \%} \\
(\mathrm{~min})\end{array}$ & $\begin{array}{c}\mathrm{k}_{\mathrm{m}} * \\
60\end{array}$ \\
\hline 45.0 & 19.2 & 0.12 & 52.0 & 13.4 & 0.17 & 41.7 & 9.8 & 0.18 \\
80 & 51.7 & 8.9 & 0.16 & 45.0 & 8.2 & 0.22 & 43.3 & 8.8 & 0.25 \\
\hline
\end{tabular}

$* \mathrm{~km}$ values in $\mathrm{cm} \mathrm{min}^{-1}$. 
Table 3. Effect of the RVC cathodes porosity on the removal rate of zinc from chloride medium.

\begin{tabular}{lccc}
\hline Porosity (ppi) & $\begin{array}{c}\mathrm{C}(0) \\
(\mathrm{mg} / \mathrm{L})\end{array}$ & $\begin{array}{c}\text { t90\% } \\
(\mathrm{min})\end{array}$ & $\begin{array}{c}\mathrm{k}_{\mathrm{m}} \\
\left(\mathrm{cm} \mathrm{min}^{-1}\right)\end{array}$ \\
\hline 45 & 59.6 & 40.0 & 0.08 \\
60 & 54.4 & 23.0 & 0.13 \\
80 & 54.4 & 16.0 & 0.16 \\
100 & 54.1 & 16.0 & 0.16 \\
\hline
\end{tabular}

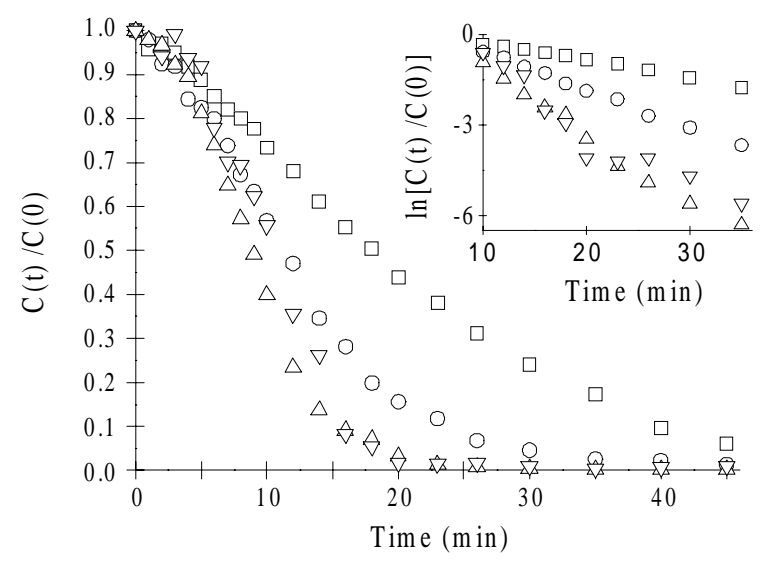

Figure 7. Normalized concentration $[(\mathrm{C}(\mathrm{t}) / \mathrm{C}(0)] v s$. time curves for zinc removal experiment, obtained for a $120 \mathrm{~L} / \mathrm{h}$ flow rate, using cathode porosities of $(\bullet) 45$, (o) 60, ( $\Delta$ ) 80 and $(\nabla) 100$ ppi. Initial Zn(II) concentration as shown in Table 3. Potential of $-1.35 \mathrm{~V} v s$. SCE. Inset: Plot of $\ln [\mathrm{C}(\mathrm{t}) / \mathrm{C}(0)] v s$. time for the data shown.

used under a flow rate of $120 \mathrm{~L} / \mathrm{h}$. After 20 to $40 \mathrm{~min}$. of electrolysis a concentration of $0.1 \mathrm{mg} / \mathrm{L}$ is reached. Table 3 shows results for zinc removal experiments using different RCV porosities. To achieve lower concentrations of $\mathrm{Zn}(\mathrm{II})$, the electrolysis demanded less time for higher porosities. This behavior reflects differences in the specific surface areas of RVC cathodes, since an increase in RVC porosity results in a larger area being available for the electrodeposition. The data show that as the porosity increases, the reduction of $\mathrm{Zn}$ (II) becomes more effective, with a clear limiting value of 80 ppi from which the mass transport coefficient, calculated using Eq. 1, becomes constant.

Although the plots for lead concentration as a function of the electrolysis time were apparently exponential, the expectation of linearity for the plot of $\ln [\mathrm{C}(\mathrm{t}) / \mathrm{C}(0)] v s$. time, shown in the inset from Fig. 6, was confirmed only for the first $30 \mathrm{~min}$. of electrolysis. For longer experiment times, when the efficiency of removal was greater than $90 \%$, a deviation from linearity occurred. The reason for that is the probable loss of current efficiency as lead is being removed. If we consider the decay of zinc shown in Fig. 7, linearity between $\ln [\mathrm{C}(\mathrm{t}) / \mathrm{C}(0)]$ and time of electrolysis commences after $10 \mathrm{~min}$. of polarization. Decay of zinc in this interval of time is a slow process, and thereafter, it assumes the expected behavior as can be seen in the inset from Fig. 7. This is an unexpected result if we compare with the data for the removal of lead. The reason for this behavior is attributed to a competitive process of chemical dissolution of the just growth zinc nuclei in the chloride medium. This effect is even more pronounced for lower values of $\mathrm{pH}$.

\section{Conclusions}

Hydrodynamic voltammetry was adequate for studying the $\mathrm{Cu}$ (II), $\mathrm{Pb}$ (II) and $\mathrm{Zn}$ (II) reduction reaction under mass transport control. The limiting current plateaus in the resulting voltammograms showed the range of potential over which the metals reduction reaction is mass-transfer controlled.

Using these potentials, the concentration of the metal ion containing solution was reduced from $\approx 50$ to $0.1 \mathrm{mg} / \mathrm{L}$ during recirculation times ranging from 20 to $40 \mathrm{~min}$., depending on the RVC porosity and the flow rate. Best rates of metals removal were obtained at the higher cathode porosities and higher flow rates.

The cell design used in this study showed a good performance in the removal of metals from simulated effluents.

\section{References}

1. H.A.Waldron, (Ed.), Metals in the environment. London: Academic Press, Ch 6, p.155-197, 1980.

2. Boeckx, R. Anal. Chem. 1986, 58, $274 \mathrm{~A}$.

3. Water Regulations Act, US Environment Protection Agency, Washington, D.C., (1989). and Brazilian Legislation: Resolução CONAMA nº. 20 (1986).

4. Alkire, R.; Ng, P.K. J. Electrochem. Soc. 1977, 124, 1220.

5. Tentorio, A.; Casolo-Ginelli, U. J. Appl. Electrochemistry 1978, 8, 195.

6. Sioda, R.E.; Piotrowska, H. Electrochim. Acta 1980, 25,331 .

7. Simonssom, D. J.Appl. Electrochemistry 1984, 14, 595.

8. Carta, R.; Palmas, S.; Polcaro, A.M.; Tola, G. ibid 1991, 21, 793. 
9.Pletcher, D.; White, I.; Walsh, F.C.; Millington, J.P. ibid 1991, 21, 659 .

10. Pletcher, D.; White, I.; Walsh, F.C.; Millington, J.P. ibid 1991, 21, 667.

11.Wang, J.; Dewald, H.D. J.Electrochem. Soc. 1983, 130, 1814.

12. Abda, M.; Gaura, Z.; Oren, Y. J.Appl. Electrochemistry 1991, 21, 734.

13. Oren, Y.; Soffer, A. Electrochim. Acta 1983, 28, 1649.
14. Matlosz, M.; Newman, J. J. Electrochem. Soc. 1986, $133,1850$.

15.Langlois, S.; Nanzer, J.O.; Coeuret, F. J. Appl. Electrochemistry 1989, 19, 736.

16. Bockris, J.O'M.; Bhardwaj, R.C.; Tennakoon, C.L.K. Analyst 1994, 119, 781.

17. Wang, J. Electrochim. Acta 1981, 26, 1721.

18. Greef, R.; Peat, R.; Peter, L.M.; Pletcher, D. In Instrumental Methods in Electrochemistry, Chichester: Ellis Horwood, 1990.

FAPESP helped in meeting the publication costs of this article 